\title{
Java Furniture Makers: Globalisation Winners or Losers?
}

\author{
Lienda Loebis \\ Hubert Schmitz
}

\begin{abstract}
Globalization is one of the most intensive subjects to be debated during the last decade, both in the developing countries and developed countries. The major question is who are the winners and the losers from the globalization. As a case study, this article attempt to investigate whether furniture makers in Central Java are winners or losers from globalisation. More specifically, it addresses two questions: first, have enterprises and workers gained from producing for the global economy? Second, are these gains sustainable? The answer to the first question is yes; however, to the second question is no, not under current circumstances.
\end{abstract}

Keywords: Globalization-Small and medium enterprises

JEL Classification: $L 50-L 70$ 


\section{INTRODUCTION}

Who loses and who gains from globalisation is one of the big questions of our time. The people of East and South East Asia were thought to be among the winners until the financial crisis hit this region in 1997. Indonesia, it seemed, suffered particularly badly with millions of people sinking into poverty. However, it soon became clear that some parts of Indonesia had actually benefited from the crisis. The sudden and large depreciation of the Rupiah raised the export competitiveness of local enterprises overnight. Agro-processing was one of the sectors that benefited most because it used local materials and required low levels of foreign currency as a result. The furniture industry of Central Java is also a good example as it grew rapidly in the wake of the crisis.

Do furniture enterprises and their workers are winners from globalisation? This is the first question addressed in this article. The second question is whether the observed growth is sustainable. We address these questions with information collected in Semarang, Jepara, and Klaten in May and June, 2003, with data from secondary sources.

In seeking answers, the article feeds into a debate which is important both for researchers and policy makers. Does participation in the global economy lead to sustainable income growth? Some contributors to this debate are sceptical; they emphasise that producing for global markets means entering a race to the bottom (Kaplinsky, 2000; Kaplinsky, Morris, and Readman, 2002). The furniture industry of Central Java is a good test case, as underlined by the spate of recent papers on this industry (Sandee, Andadari, and Sulandjari, 2000; Sandee, 2002; Sulandjari and Rupidara 2002; Muhtaman, 2003; Posthuma, 2003). This article contributes to this debate in three ways:

First, it records the gains that have been made. The growth in the number of enterprises and in the number of jobs is undeniable, as shown in Table 1. The article further suggests that the earnings of workers have increased substantially.

Second, in line with other recent contributions, the article questions the industry's prospects for further growth. On the input side, the industry is suffering from increasing scarcity and cost of raw materials. On the output side, it is suffering from intensifying competition from Vietnam, China and other countries. In spite of this undeniable squeeze, the producers themselves are surprisingly optimistic. How can one explain this?

Third, the article connects findings from this case study to the debate on SME promotion. Does support for SMEs (small and mediumsized enterprises) only drive them deeper into the race to the bottom? Averting this danger, we conclude, requires a coalition of actors along 
the local-global axis. These policy issues are, however, merely laid out and not discussed in detail.

Table 1

Number of Firms and Workers in Jepara, 1997-2002

\begin{tabular}{|l|l|l|l|l|l|l|}
\hline & 1997 & 1998 & 1999 & 2000 & 2001 & 2002 \\
\hline Total Firms & 2,439 & 3,008 & 3,965 & 3,400 & 3,593 & 3,700 \\
\hline Total Workers & 38,264 & 43,916 & 45,780 & 57,000 & 57,488 & 58,210 \\
\hline
\end{tabular}

Source: District Office of Industry, Trade and Cooperatives, Jepara

\section{THE LOW AND THE HIGH ROAD TO COMPETITIVENESS}

There are two ways local enterprises can compete in the global economy. Taking the low road means competing by paying the lowest possible wages, disregarding environmental standards and avoiding taxes. Taking the high road means competing by upgrading processes and products. In the furniture industry of Central Java one finds examples of both.

There is no secret that many enterprises have taken the low road. The majority of enterprises, especially the smaller ones, are not registered. By implication, their workers are not registered either. According to recent estimates, $83 \%$ of Central Java furniture enterprises and $67 \%$ of workers are 'informal' (Sulandjari and Rupidara, 2002). Taxes and social security payments are thus avoided on a big scale. While this practice is widespread, there is no consensus on whether registration should be enforced. Some argue that the informal sector is a source of future growth, while others argue that this informality traps small producers in low productivity and low profit activities.

No such disagreement exists on another dimension of low road competition, i.e. the use of illegal raw materials. This practice is increasingly common in the furniture industry. Muhtaman (2003) concludes that the overuse of forests and inadequate management practices have in many cases depleted the resource base for the industry and as a consequence undermined the sustainability of the wood based industry'. It is estimated that the rate of forest loss in Indonesia has accelerated from 1 million hectare per year in the 1980s to 2 million hectare per year since 1996 (IIED/ICTSD 2003).

Forest management and the sale of timber are entrusted to the state enterprise Perhutani. It continues to be the main source of wood, especially teak, but an increasing share of wood is available from thieves. Illegal trade is thriving and particularly damaging because many of the trees are under-age (Muhtaman, 2003). There is a consensus that illegal 
logging damages both the short term and long term prospects of the industry. It undermines those competing enterprises that use legally acquired wood. It also accelerates deforestation and thus threatens the long term viability of this industry (Posthuma, 2003).

\section{LOCAL UPGRADING IN GLOBAL CHAINS}

One way forward is to upgrade products and processes. How can local enterprises achieve this? Local cluster theory emphasises that the knowledge needed for upgrading comes from within the cluster. Global value chain theory emphasises that the know-how comes from outside the cluster, in particular from global buyers (Humphrey, Schmitz, 2002; Humphrey, 2003; Schmitz 2003). Some furniture enterprises in Central Java were able to grow and upgrade rapidly by inserting themselves in global value chains. We were able to confirm this in the course of our factory visits and interviews. Take the company Duta Jepara, for example. It has 850 workers and produces garden furniture made from teak wood. The entire output is exported, more than half going to three Scandinavian buyers. Duta Jepara has long standing relationships with these customers, who exert pressure and provide support for upgrading products and processes. Or take the company Suwastama, located near Solo, which has 650 workers and produces rattan and other furniture mainly for the Swedish company IKEA. Suwastama in turn has 350 suppliers who have further subcontractors. It is a buyer-driven value chain that provides over 7000 jobs and constitutes one of the biggest Java success stories. Key to this success is Suwastama's programme of enabling its suppliers to improve quality and timely delivery. This foster role vis-à-vis its suppliers could only develop in the context of a relationship with a foreign customer providing innovative designs and regular large orders.

\subsection{The role of buyers:}

This is not to suggest that large Indonesian manufacturers have easy relationships with their foreign customers. On the contrary, the manufacturers find themselves in captive relationships with their Scandinavian buyers. In itself, this is not necessarily a problem because there is a mutual commitment between producer and buyer to solve difficulties jointly rather than terminate the relationship. Rather, the problem arises in that these same global buyers have also begun to buy furniture in Vietnam and China. This means intensifying competition and shrinking profit margins for Indonesian manufacturers. They informed us that margins have decreased by 20 percent or more since 
2000. However, in spite of the squeeze on profits, we can conclude that the local suppliers have benefited from the close albeit captive relationship with their big customers.

Small and medium sized enterprises (SMEs) also produce for global markets but the relationships with their buyers tend to be different; in most cases they are purely market-based. Like the large enterprises, SMEs are demand-driven but they rarely enjoy information-rich relationships with their buyers. Neither producers nor buyers invest in their relationships. We visited a number of such enterprises. Take the example of Aulia Ariffin (real case but name modified to protect identity) in Jepara. His enterprise is informal, employs 17 workers and makes many different types of furniture. He has many customers but these customers do not help to improve products and processes. Ariffin's initial stock of knowledge was 'inherited', i.e. it came from working with his father. Now he relies entirely on learning by doing and copying from other enterprises in Jepara. Since Jepara is a cluster with over 3000 furniture producers, it attracts many traders that connect the many small enterprises to distant markets in Indonesia and abroad. Being located in this cluster thus offers small enterprises easy access to buyers, but the relationships with these buyers rarely contains the combination of challenge and support that leads to upgrading. In fact, product quality tends to be inconsistent, and the wastage of raw material tends to be high.

\subsection{Entrepreneur optimism:}

It would be wrong to give the impression that all large enterprises are progressive and all small enterprises are backward. Such stereotypes are unhelpful and misleading. There are a number of small enterprises that have made enormous progress and many large enterprises that adopt dubious practices. Above all, there is a dynamic middle segment of enterprises that are registered, have specialised in particular niche markets and developed their own designs. They showed us their new products with much pride and displayed a refreshing optimism about their future.

Surprisingly, such optimism also prevailed among the small entrepreneurs who were competing on the low road. We found this optimism surprising because there are so many of them. According to the Provincial Office of Industry, Trade and Cooperatives, there are about 3500 enterprises in Jepara; the vast majority of them are of micro and small size. Even though they are not registered, they are easy to find. One sees them by just driving or walking around Jepara and its near-by 
villages. It is impressive how much hard work goes into these small businesses. But their operations are clearly precarious and the competition is intense. So what explains the optimism that we found among the owners we spoke to? The answer they gave was that the customers kept coming.

We cannot, however, generalise from Jepara to other clusters. This became particularly clear when we visited Serenan, a younger and less known furniture cluster near Klaten. Enterprises in this cluster have also benefited from the export boom of the 1990s but are now struggling to find customers (mid-2003). The contrast between Serenan and Jepara was striking. Being located in Jepara's established and famous cluster gives its producers easier access to customers; this seems one reason for the optimism of Jepara's producers. (1) But this is not to suggest that the views and experiences within these clusters are uniform.

While the experiences and prospects of furniture makers in Central Java vary, there is a common factor which has a huge influence on the ability to compete and which the producers do not like to talk about: they cut corners to reduce costs and remain competitive. Using illegal wood is an enormous cost saver. Raw material accounts for about 60 percent of the cost of most teak furniture, so acquiring cheaper (illegal) wood makes a huge difference to both price and profit.

\section{THE DILEMMA OF SUPPORT INSTITUTIONS ${ }^{1}$}

Such low road practices pose a dilemma for the Indonesian and foreign donor organisations concerned with small enterprise development. On the one hand, assisting small enterprises can result in support of the illegal wood trade. On the other hand, small enterprises provide significant levels of employment and income. For the time being, the support for small enterprises continues. For example, the Ministry of Industry and Trade has the Department for Small and Medium Enterprises, a very active Department which specifically targets SMEs and works closely with business associations such as ASMINDO (2). The work of these public and private organisations is sometimes

\footnotetext{
${ }^{1}$ Notes

1 Sandee, Isdijoso and Sulandjari (2002) hold a more pessimistic view of Jepara's prospects.

2 The Association of the Furniture Industry

3 Japan International Cooperation Agency

4 Deutsche Gesellschaft für Technische Zusammenarbeit (German Agency for Technical Cooperation)

5 Asian Development Bank

6 International Labour Organization

7 United Nations Industrial Development Organization
} 
complemented by donor projects, some of which we have followed closely (through direct visits or evaluations). For example, JICA (3) has an interesting pilot project that involves strengthening the clusters of Sidoarjo (metalwork), Kebumen (tiles) and Serenan (furniture). Similarly, GTZ (4), ADB (5), ILO (6) and UNIDO (7) have projects to support small enterprises in specific regions and sectors of the Indonesian economy. These are all concerned with enhancing the competitiveness of small entrepreneurs and are doing good work in the localities in which they operate. The problem is that opportunities and dangers often originate from outside the locality.

Our visits to Semarang, Jepara, and Klaten and our discussions with business people in other locations made it clear that we need a wider perspective if we want to understand the prospects for SMEs. We need to understand the global value chain in which these SMEs operate. The furniture case makes this very clear. Furniture chains are buyerdriven and upgrading prospects depend very much on the type of relationships producers have with their buyers as we stressed earlier.

Understanding what goes on at the other end of the chain is equally important. Much of the furniture industry of Central Java depends on a continuing supply of teak but this supply is in danger. The big buyers know this as do their customers who buy the furniture in European stores. This is why big buyers insist on certification that the wood comes from well-managed forests. Perhutani, the state company responsible for these forests, used to provide such certificates, but has now suspended certification, partly because it has lost control of the timber trade. As a result, even responsible furniture manufacturers are unable to provide certificates about the origin of the wood. Although their buyers have accepted this, any optimism that buyer pressure would help to stop illegal wood trade has collapsed. It is clear to all involved that current practices are not sustainable, and yet they still continue.

The need to examine the problems of SMEs in the context of the value chains in which they operate is beginning to be recognised by policy makers. For example, the Ministry of Industry and Trade and the International Labour Office held a joint workshop entitled 'Value Chain Analysis for Policy Makers' in Jakarta at the end of April 2003. What drives the chain? Where are the key bottlenecks? Which actors need to be brought together to hammer out a solution? These questions need answers and the global value chain approach provides a fresh way of understanding the problems and forging alliances for change. Policy makers, business leaders and researchers present at the workshop agreed that it is time to experiment with new approaches which bring together progressive actors along a local - global axis. 
The furniture industry of Central Java is a good test case. The industry has been very successful in recent years but its sustainability is in doubt. Can the enterprises upgrade sufficiently and escape the relentless low price competition from China and Vietnam? Can more effective regulation of the forests and the timber trade be put in place? We do not know the answers but we know that expectations are high. The entrepreneurs we spoke to are optimistic. For example, Akhmad Fauzi, the leader of the Jepara furniture association, spoke enthusiastically about his upgrading initiatives.

\section{EMPLOYMENT, INCOME, AND MOTOR CYCLES}

Such optimism also seems to prevail among workers in this industry. They expect the upward trend of the past few years to continue. The increase in employment opportunities is clear in the statistics. In Jepara, employment in the furniture industry increased from 38,264 in 1997 to 58,210 in 2002 (see Table 1). Although precise statistics are not available for wages, Herry Purwanto, Head of the District Office for Industry, Trade and Cooperatives, estimates that wages have risen by 10 to 15 percent (in real terms) per year from 1997 to 2002. Increases in real wages in domestic currency overstate the international purchasing power of these wages due to devaluation, but there is no denying that workers are better off. The general improvement of workers' earnings is reflected in the statistics on registered motorcycles; in Jepara, the total number of registered motorcycles increased by 53.6\% from 1998 to 2001 (data provided by the District Office of Industry, Trade and Cooperatives).

In the absence of reliable income statistics, data on motorcycle sales and registration are a useful proxy for observing income changes. Motorcycles are the workers' favourite form of transportation and ownership represents gains in living standards. Direct observation provides clear examples. As one drives into the grounds of the Duta Jepara factory, what catches the eye is the parking bay with hundreds of motorcycles. There is hardly a bicycle to be seen. When the shift ends, the young workers show off their shiny acquisitions - keen to be seen on their motorised two-wheelers. The motorcycle is a status symbol amongst workers. And it is not just the men that use motorcycles; they are also popular amongst women.

Merging available statistics and casual observation, it appears that export-oriented Jepara is better off than other small towns and that prosperity in Jepara has increased over recent years. Can we therefore conclude that the Jepara furniture manufacturers and their workers are globalisation winners? Our answer is yes, but we must also stress our doubts over whether the gains are sustainable. 


\section{WHAT CAN GOVERNMENT DO?}

The clearest policy implication is that sole reliance on the market would be a disaster. Participating in the global market has brought many benefits to the furniture industry but competitive pressures are now dragging the industry into a race to the bottom. What can be done to nudge the industry from the low to the high road? This is a big question to which this short article can only begin to provide answers.

The positive policy implications are clear in principle, but they are complicated in practice. The immediate priority lies in halting the plundering of forests. Stronger state intervention is urgently needed but not forthcoming as the Indonesian state is in the process of decentralising. In principle, devolving powers to the provincial and district levels could help to regain control over the forests, but the process of devolution is slow and painful. At best it will lead to uneven progress, at worst it will lead to a protracted power vacuum in which theft and corruption continue to thrive.

Given the difficulty of solving the problem at the supply end of the chain, initiatives are underway to curb demand. The Government of Indonesia is preparing a memorandum of understanding with the European Union and Japan which would ban the entry of illegal logs into their respective countries. Enforcing such bans, however, is difficult and other parallel measures will need to be adopted. Many schemes are being discussed in national and international fora. Here is just one example: allocate a designated share of existing forests to a consortium of furniture producers and buyers; then let this consortium manage this share so that the sustainability of the participating enterprises is ensured. Such a scheme would benefit certain market segments in which certified ecological responsibility is critical. Since competition in these segments is less price-driven, there would be less conflict between short term profitability and social responsibility.

Encouraging private production is another important line of action. In fact, the state enterprise Perhutani is already doing so. Perhaps this deserves more emphasis. Similarly, community forests also deserve more attention. International experience suggests that local communities are an undervalued force in responsible forest management.

Ensuring a sustainable supply of raw material is the first policy priority. The second priority is to help the industry upgrade its products and processes. As stressed above, global buyers can provide a fast track for such improvements but few small producers can gain access to this. They rely on business development services, notably for training, testing, supply chain management, and certification. It is widely recognised that 
such services are best provided in conjunction with business associations or other private actors.

The problem is that producers often do not recognise their need to upgrade and are reluctant to follow the advice of consultants. Producers are more likely to listen to their customers. Therefore, support programmes should confront small producers with customers' perceptions of their shortcomings. There are now simple but effective techniques for doing this.

The most difficult areas in which to lend effective support are design and marketing. There is no agreement on 'best practices' for such support so the only way forward is experimentation. There is, however, no doubt about the importance of fostering design and marketing capabilities. Without such capabilities it will be difficult to achieve better prices and higher incomes.

\section{CONCLUSION}

This article investigated whether furniture makers in Central Java are winners or losers from globalisation. More specifically, it addressed two questions: first, have enterprises and workers gained from producing for the global economy? Second, are these gains sustainable? Our answer to the first question is Yes; our answer to the second question is No, not under current circumstances.

Given the pessimism that has beset much of the globalisation debate it is important to record that gains in employment growth and income growth have been substantial. Most of this employment and income growth has been generated by small and medium enterprises which were able to benefit from the financial crisis of late-1997 and increase their exports.

The viability of these exports is dependent on a resource endangered by depletion. An increasing part of the raw material, especially teak, comes from illegal sources. Illegally felled timber tends to be younger and thus threatens the sustainability of the forests. Halting this process is difficult as intensifying price competition in the international market leads enterprises to prefer cheaper illegal wood.

No single actor and no single measure can reverse this process. Stricter state control of the timber supply is essential but top-down directives will be insufficient. Local communities play an important role in socially responsible use of forests. Helping furniture enterprises redirect their competitive strategy also plays a role. Relying on cheap raw material for competing in global markets is not a viable strategy. In the future competition will be centred on the basis of quality, design and 
image. Using wood from a certified source is an important part of changing the image. Helping enterprises to make this switch is not easy. Understanding the relevant global value chain(s) is an important first step for making this switch.

\section{REFERENCES}

Humphrey, J.,2003, Opportunities for SMEs in Developing Countries to Upgrade in the Global Economy, International Labour Organisation SEED Working Paper 43.

and H. Schmitz, 2002, "How does Insertion in Global Value Chains Affect Upgrading in Industrial Clusters?", Regional Studies 36(9):1017-1027.

IIED/ICTSD,2003, Trade and forests: Why forest issues require attention in trade negotiations, Policy Views on Trade and Natural Resource Management, London and Geneva: International Institute for Environment and Development and International Centre for Trade and Sustainable Development.

Kaplinsky, R., 2000, Globalisation and Unequalisation: What can be Learned from Value Chain Analysis? , Journal of Development Studies 37(2):117-146.

, M. Morris and J. Readman, 2002, The Globalisation of Product Markets and Immiserising Growth: Lessons from the South African Furniture Industry, World Development 30(7):11591178.

Muhtaman, D. R., 2003, Raw Material Supply for the MSME Furniture Industry in Central Java, Bogor: SmartWood.

Posthuma, A. C.,2003, Taking a seat in the global market place: Opportunities for "high road" upgrading in the Indonesian wood furniture sector?, Mimeo, Geneva: InFocus Programme on Boosting Employment through Small Enterprise Development, International Labour Organisation.

Sandee, H.,2002, "The Impact of the Crisis on Small-Scale Enterprises in Java: Findings from Selected Case Studies", in M. P. van Dijk and H. Sandee (eds.) Innovation and Small Enterprises in the Third World, Cheltenham: Edward Elgar.

K. Andadari and S. Sulandjari, 2000, 'Small Firm Development During Good Times and Bad: The Jepara Furniture Industry', in C. Manning and P. van Diermen (eds.), Indonesia in Transition, Singapore: Institute of Southeast Asian Studies. 
B. Isdijoso and S. Sulandjari, 2002, SME Clusters in Indonesia: An Analysis of Growth Dynamics and Employment Conditions, Jakarta: International Labour Office.

Schmitz, H. (ed.), 2003, Local Enterprises in the Global Economy: Issues of Governance and Upgrading, Cheltenham: Edward Elgar, forthcoming.

Sulandjari, S. and N. S. Rupidara, 2002, Value Chain Analysis of Wood Furniture Clusters in Central Java, draft report, Salatiga: Centre for Micro and Small Enterprise Dynamics. 


\section{Contributors to This Issue}

Anton Hendranata

Arianto A. Patunru

Bambang P.S. B

Bonar M. Sinaga

Hubert Schmitz

Iwan J. Azis

Lienda Loebis

Miranda S. Gultom

Willem Thorbecke
: Researcher, Institute for Economic and Social Research, Faculty of Economics University of Indonesia, Jakarta

: Researcher, Institute for Economic and Social Research, Faculty of Economics University of Indonesia, Jakarta

Chairman, Department of Economics, Faculty of Economics University of Indonesia, Jakarta

Chairman, Graduate Program in Agriculture, Bogor Agricultural Institute, IPB, Bogor

Institute of Development Studies at the University of Sussex, Falmer, Brighton, UK

: Professor, Cornell University, Ithaca, NY 14853, USA

Ministry of Industry and Trade, Jakarta

Senior Deputy Governor of Bank Indonesia;

Department of Economics, Faculty of

Economics University of Indonesia

Professor, Department of Economics, George Mason University, Fairfax, VA, 22030, USA. 